\title{
Turkey's Development Assistance to Fragile States: From Sporadic Actions To System Building Practices
}

\section{Deniz Göle*}

\begin{abstract}
This article aims at presenting policy recommendations for Turkish decision makers with a view to address Turkey's needs to ensure effective and timely development assistance to fragile states. The analysis begins with a quick look at the controversial relation between aid, growth and poverty in order to provide a basis for understanding aid effectiveness as well as some of the ongoing debates and limitations in the development assistance field. It then gives an insight on the current state of Turkey's development assistance to fragile states and briefly explains major characteristics of Turkey's aid policies and practices in fragile state contexts. The study focuses on describing the necessity for shifting Turkey's development assistance paradigm and is concluded with recommending a new paradigm along with its operational framework in three pillars namely; Institutionalizing Peace, Building the Functional State and Risk Distribution.
\end{abstract}

Keywords: Foreign Aid, Official Development Assistance, Growth, Poverty, Turkey, Fragile State, Peace Building, State Building

\footnotetext{
* Planning Specialist, General Directorate of External Economic Relations, Ministry of Development of the Republic of Turkey, deniz.gole@ @alkinma.gov.tr
} 


\section{Introduction}

In recent years, Turkey has been spotlighted due to its remarkable development assistance performance. Receiving cooperation proposals from experienced actors in the field as well as new ones like China and India, this new emerging donor is at the forefront of international community in these days. In spite of its membership to the OECD and voluntary reporting to OECD's Development Assistance Committee (DAC), Turkey's characteristics of assistance distinguish the country from traditional donors. Nevertheless, country's "modernization" quest started in the $19^{\text {th }}$ century to internalizing mostly European values and institutional structures also prevents Turkey to be entirely deemed as an emerging donor.

Studies thus far on Turkey's development assistance mainly concentrate on region, country or sector level analyses. However, there is no research focusing on the peculiarities of Turkey's assistance to conflict affected states, usually referred as fragile ${ }^{1}$, even though two thirds of Turkey's development aid has been delivered to these countries ${ }^{2}$. Hence, it is very unfortunate for Turkish policy and decision makers to overlook this particular aspect especially when the issue has recently been discussed thoroughly at the global level.

Most of the countries located in the Middle East, North Africa and Central Asia are primarily at the center of Turkey's assistance. Yet, there are others such as Myanmar and Somalia, which turn onto Turkey thanks to its identity successfully harmonizing the western ideals like democracy, rule of law, secularity with oriental values like spiritualism and collectivism. These countries, to a large extent, have been unable to establish a stable public authority due to both internal and external factors ${ }^{3}$. Furthermore, struggled with violent conflicts, they have also failed to establish sound social and economic infrastructure, which has caused paramount deprivation and challenging conditions.

Turkey, on the other hand, simply does not have tailor-made policies and practical tools to address fragility, although a significant amount of Turkish development aid has been delivered to countries in such condition. Therefore, lack of efficient state mechanisms along with ongoing violence in fragile states make it more difficult for Turkey to ensure aid effectiveness ${ }^{4}$. Moreover, the issue is not only about improving effectiveness but also averting risks. Aid practices ignoring genuine challenges in fragile states cause substantial risks for both donors and recipients.

In this respect, this article mainly aims at presenting policy recommendations for Turkish decision makers with a view to address Turkey's needs to ensure effective and timely aid to fragile states. The analysis begins with a quick look at the controversial relation between aid, growth and poverty in order to provide a basis for understanding aid effectiveness as well as some of the ongoing debates and limitations in the development assistance field. It then gives an insight on the current state of Turkey's development assistance to fragile states and briefly explains major characteristics of Turkey's aid policies and practices in fragile state contexts. The study is concluded with describing the necessity for shifting Turkey's development assistance paradigm and establishing new paradigm's framework in three pillars namely; Institutionalizing Peace, Building Functional State, Risk Distribution.

\section{Quick Look at Aid, Growth and Poverty}

Turkey's ODA volume has significantly increased over the last three years and this trend is expected to continue in 2013. Nevertheless, increased volume does not necessarily mean increased effectiveness. The study performed by Radelet, Clemens and Bhavnani (RCB) revealed that the larger the aid was, the smaller was the additional economic growth of recipient country from that additional injection of aid. What's more interesting is that aid has a zero effect when it reaches the 8 percent of recipient country GDP ${ }^{5}$ and after that it has a negative effect on growth ${ }^{6}$. 


\section{Deniz Göle}

Knack further claims that higher aid usually lowers bureaucratic quality, causes violation of the law and thereby hinders democracy as well as governance ${ }^{7}$.

Further findings of the RCB study have other interesting implications for Turkey's assistance. It presents that the most effective types of aid with a significant impact on growth in the short-term are economic and production sectors along with budget support ${ }^{8}$. According to study's results, building economic infrastructure, improving services and supporting production sectors such as agriculture, industry and trade have fairly immediate positive effect on growth (short-impact aid).

Evidence on short-impact aid is, indeed, convincing. Nevertheless, it does not necessarily suggest dwelling on "sacred solutions" or panaceas for development challenges. On the contrary, breaking taboos is the key for effective and tailor-made assistance. For instance, an article published by World Bank economists proved that there was no evidence suggesting small and medium sized enterprises (SMEs), supposedly the catalysts for poverty alleviation in all contexts, create economic growth or reduce poverty. Although, many donors promote it particularly in least developed environments, firm size does not have anything to do with economic growth ${ }^{9}$.

Different circumstances in different countries lead to various challenges that cannot be dealt with one-fit-for-all solutions. That is why, most of the aid initiatives aiming at imposing Western values and institutions in advance fail. An important study by Fafchamps and Minten presented that there could be other alternatives and solutions for development issues. They claimed that, instead of the free market "ideal" of the West, Africa has developed a "flea market economy" which, to some extent, managed to protect property rights and ensured sustainable trade relations in creative ways ${ }^{10}$.

Nonetheless, the real question is how to identify, analyze and deal with country specific development challenges. Sachs suggested under his "clinical economics" methodology that "[Providing economic advice and development assistance] requires commitment to be thoroughly steeped in the history, ethnography, politics and economics of any place [...]" To do that and ensure aid effectiveness, he proposed a "differential diagnosis" approach which dwells on poverty trap, economic policy framework, fiscal framework and fiscal trap, physical geography, governance patterns and failures, cultural barriers and geopolitics of any given recipient country ${ }^{11}$. Easterly, on the other hand, opposes big plans, which would, supposedly, end poverty via overarching ambitious schemes. Instead, he advocates piecemeal actions to be performed by people (searchers) with constructive and creative approaches to foreign aid who should be held accountable and provided feedback. He asserts that big plans usually distract development practitioners from what is actually needed in the field such as keeping roads in good conditions or pursuing good monetary policies to prevent inflation. Still, like Sachs, Easterly admits that "poverty is a complicated tangle of political, social, historical, institutional and technological factors" and therefore needs differentiated solutions ${ }^{12}$.

The answer is somewhere in between. Easterly makes a good case in claiming that comprehensive plans to reform recipient country policies and institutions often prevent donors to comprehend the realities in the field, which, to certain extent, can be addressed by practical solutions. Nevertheless, lack of planning would almost certainly lead to inefficient use of resources since that donors without plan basically focus on "what is available" rather than "what is needed".

\section{An Overview of Turkish Development Assistance to Fragile States}

Graphic $1.1^{13}$ shows the dramatic increase in Turkey's assistance to fragile states from 2004 to 2011. While only 94 million USD of Turkey's Official Development Assistance (ODA) was delivered to fragile states in 2004, by increasing 1540 percent, this amount has exceeded 1.5 billion USD in 2012. 


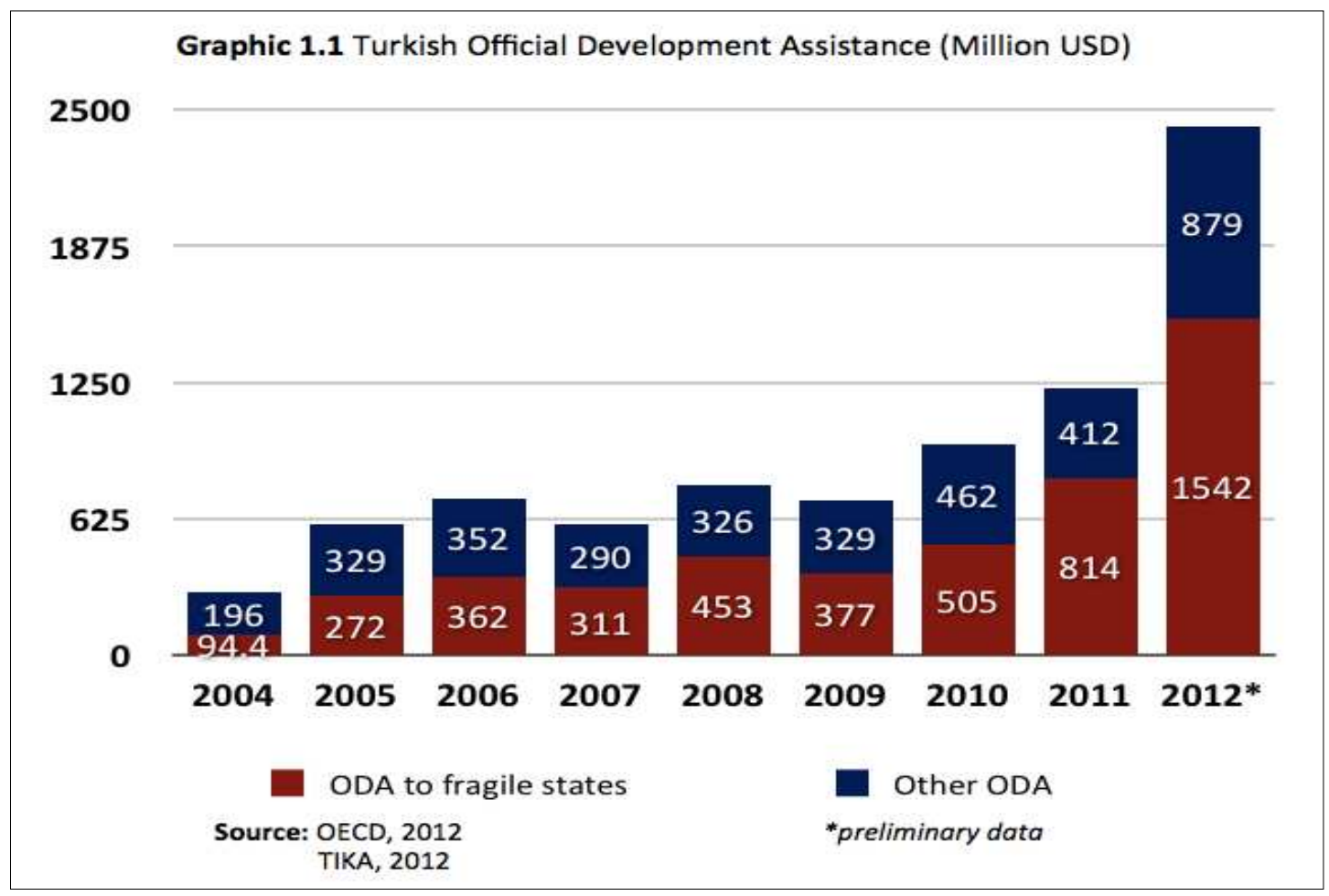

The share of Turkish ODA to fragile states exceeded the share of other countries in 2006 and continued to dominate Turkey's overall development assistance throughout the second half of the decade. Furthermore, the amount of Turkish ODA to fragile states has reached to two thirds of total

Turkish aid in 2011, albeit this share slightly decreased in 2012. Looking at the distribution of Turkish ODA on a country basis, it can be seen that the top five recipients are all states in prolonging crises (Graphic $1.2^{14}$ ). In terms of total volume of ODA between 2007 and 2011, Afghanistan is the top recipient followed by Pakistan, Kyrgyzstan and Iraq, which have always been within the top ten for the last ten years. On the other hand, Syria, the fifth top recipient between 2007 and 2011, has averagely received 4 million USD of ODA in average until 2012. In 2012, however, over 1 billion USD was allocated due to the massive inflow of Syrian refugees making Syria the top recipient of Turkish ODA.

In terms of aid volume, the gap between the top five recipients and the rest is remarkable. The total aid delivered to top five fragile states is equal to 46 percent of Turkish ODA. Moreover, if the amount of

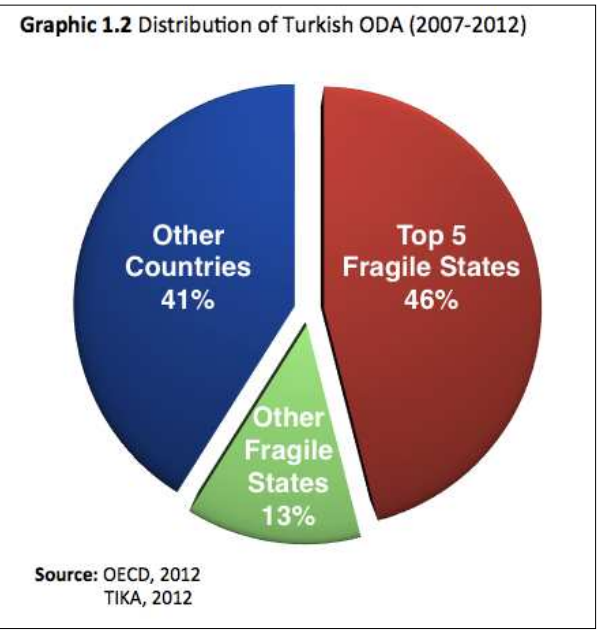
aid to other fragile states is included, the number climbs up to 59 percent. 34 out of 47 fragile states ${ }^{15}$ have received less than 100 million USD which is the annual average of Turkish ODA to these countries between 2004 and 2012. In other words, Turkey's development assistance primarily focuses on a few fragile states. According to OECD criteria ${ }^{16}, 51$ percent of Turkey's ODA to fragile states in 2011 is classified as "concentrated" and "concentrated and significant". While this "concentration" and "significance" cover only 15 fragile states, aid delivered to rest of them (32 countries) is classified as "non-significant". 


\section{Deniz Göle}

Such concentration often leads to occurrence of "aid darlings" and "aid orphans" even though concentration is usually preferred in terms of effectiveness. Nonetheless, Turkey's ODA is unlikely to cause inequalities among recipients and therefore do harm since that there has been a

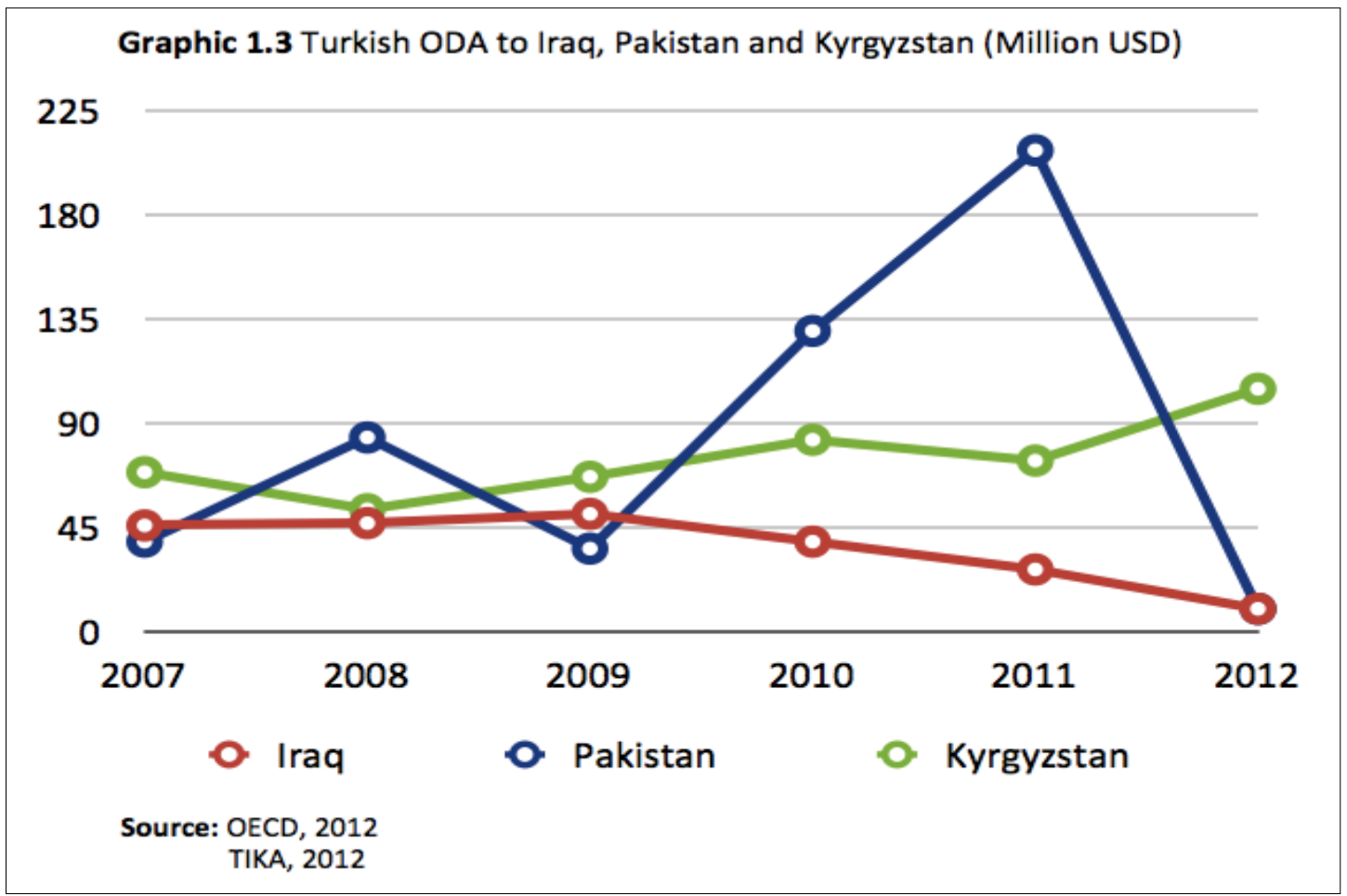

relative balance in terms of aid volume between countries having similar demands and/or located in the same region. Aid volatility, on the other hand, poses a serious risk for both Turkey and recipients. Turkish ODA to top 4 recipients has fluctuated dramatically from 2007 to 2012. Referred as "stop and go engagement" by the donor community, these alterations, first and foremost, are the symptoms of inadequate or even lack of planning which is detrimental to both sides (Graphic $1.3^{17}$ ).

Aid volatility, which causes remarkable setbacks not only for fragile states but all ODA recipients, substantially undermines donors' efforts in fragile states since that eradicating state fragility requires stability and sustainability of development assistance. Dramatic changes in ODA usually mean prioritizing urgent needs (pet projects) in the expense of long-term development objectives, which generally is the case for Turkey's development assistance to fragile states. In addition, Turkey's aid volatility has been exacerbated with the intensification of Turkish ODA operations and increased aid volume due to the lack of a holistic approach. For instance, the total amount of Turkey's humanitarian assistance has increased to 264.5 million USD in $2011^{18}$ from 179 million USD in 2005 without linking it to other aspects of ODA. Lack of long-term development assistance programs would, in turn, probably leave these countries vulnerable to internal and external shocks in the post-emergency era.

Between 2007 and $2011^{19}$, the sectoral distribution statistics for Turkish ODA reveals different results due to different classifications by OECD and Turkish Cooperation and Coordination Agency (TIKA). As a non-DAC OECD member, Turkey does not report its aid data in line with OECD's sectoral and modality-based classifications. As a result, data in OECD database is relatively limited. According to this source, Turkey's ODA to fragile states between 2007 and 2011 is annually allocated for humanitarian assistance (16\%) and technical cooperation $(13 \%)$. The rest $(71 \%)$ is deemed as "unclassified" ${ }^{20}$. In contrast, data published by TIKA provides a broader perspective. According to TIKA statistics, 44 percent of Turkish ODA projects in fragile states between 2007 and 2011 were carried out via three modalities namely technical 
cooperation, programmed aid and scholarships. The rest is shared between peace building (22\%), aid flows for refugees (20\%) and humanitarian assistance (14\%).

Peace building statistics are annually reported by TIKA in cooperation with Turkish General Staff. The share of peace-building (22\%) in total Turkish ODA indicates Turkey's significant focus on establishing peace within recipient countries. Looking at the content of these activities, however, one can assert that they are basically about keeping peace rather than building it. As it is described in the Box 1.1, Turkey's "peace building" activities are mostly designed to

\section{Box 1.1 "Peace Building” Efforts Under Turkish ODA ${ }^{22}$}

The majority of Turkey's peace building efforts has been taking place in Afghanistan. The 85 percent of the amount (60 million USD) allocated for peace building between 2007 and 2011 was earmarked for operations in Afghanistan. This is primarily due to Turkey's leading role in the Kabul Regional Command under ISAF between 2009 and 2013.

Turkey which has carried out its Afghanistan aid operations with 1650 personnel ranked $8^{\text {th }}$ among 50 countries in terms of the number of staff. Activities in this country consist of, among others, training of Afghan National Army and maintaining the order and safety of Afghan community.

Based on UN Security Council Resolutions, Turkey has also participated in the peace-building activities in Lebanon with one construction squad, several ships and some other surface elements. These teams have engaged in, inter alia, construction of headquarters, maintenance services for military facilities and rehabilitation of communication lines.

In addition, between 2007 and 2011 Turkey has annually provided 4 million USD with a view to build and maintain peace in several other fragile states located in Sub Saharan Africa, Far-East, Central Asia and Caucasia.

maintain security, build capacity for military and police forces as well as rehabilitation of related infrastructure $^{21}$. These activities simply do not have the impact, which enable Turkey to address the profound needs of fragile states such as settling conflicts, breaking cycles of violence and institutionalizing peace. They rather focus on building public institutional capacity (law enforcement capacity to be specific) with improving physical infrastructure to some extent.

Education and Health sectors as well as Water Supply and Sanitation are the main focus of Turkey's ODA not only towards fragile states but also others. Classified as "Social Infrastructure and Services" under the OECD methodology, this particular field represents 50 percent of Turkey's assistance to fragile states between 2008 and 2012 (Graphic 1.423). Under this component, education sector takes the lion's share (54\%) followed by the health sector (Graphic $1.5^{24}$ ). Even though state and peace building assistance together represent only 21 percent of social infrastructure item of Turkish ODA, total amount allocated for them has steadily increased since 2010 due to unstable conditions arisen in the post-Arab Spring era. 


\section{Deniz Göle}

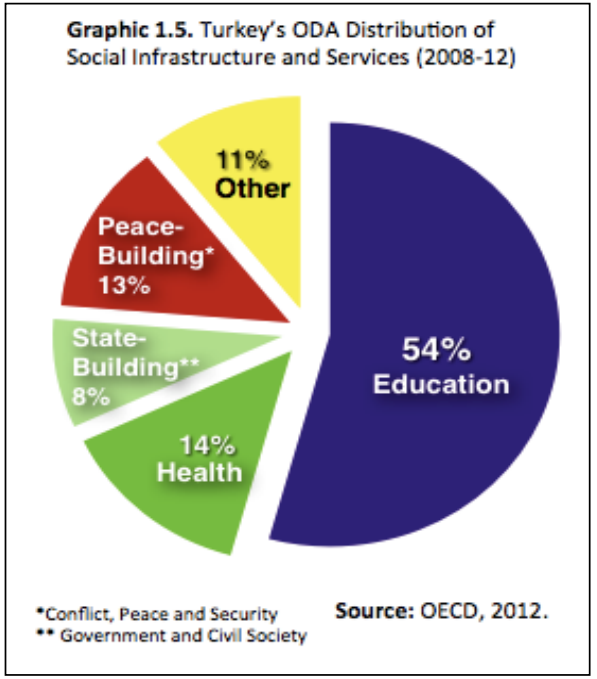

Administrative costs have also been on the rise since 2009. Nevertheless, this increase is mainly due to better reporting in terms of compliance with international standards. The sharp decline in "Unallocated/Unspecified" aid is closely linked with more accurate reporting as well. Amount allocated for scholarships, which have also been under reported in the past, have also increased to 96 million USD in 2012. This progress stems not only from proper reporting but also better coordination and collaboration between Turkish public institutions thanks to "Türkiye Scholarships" Program.

Aid towards Economic Infrastructure sectors has, on the other hand, decreased on a yearly basis since 2008 . Deteriorating security, lack of rule of law and other basic services, which prevent Turkey to carry out aid endeavors on sectors as energy, transport and financial services have led to a decline and relatively low level of aid in this sector. Aid volatility in production sectors further raise concerns since that these income-generating sectors (agriculture, industry, trade, tourism etc.), along with economic infrastructure sectors, are the main impetus of economic development and structural transformation particularly in fragile states. It is clear from the Graphic 1.4 that Turkey have allocated considerably small amount of resources to economic and production sectors. Between 2008 and 2012, aid towards production and economic sectors represent only 9 percent of Turkish ODA to fragile states.

As for the dramatic increase in the "Multi-Sector/Cross Cutting" component, detailed data cannot be obtained. Nonetheless, this sudden alteration might originate from Turkey's considerable budget support, having several multi-sectoral aspects, to countries affected from the Arab Spring (Egypt, Tunisia, Yemen etc.).

\section{Looking Beyond}

Turkish ODA to fragile states shall be qualified as constructive yet limited in terms of efficiency. It struggles with several shortcomings but possesses various remarkable assets. Looking beyond the snapshot of aid statistics, however, is necessary to comprehend the major characteristics of Turkish ODA to fragile states including its strengths and weaknesses as well as the opportunities provided and threats posed by internal and external factors.

As an emerging donor,

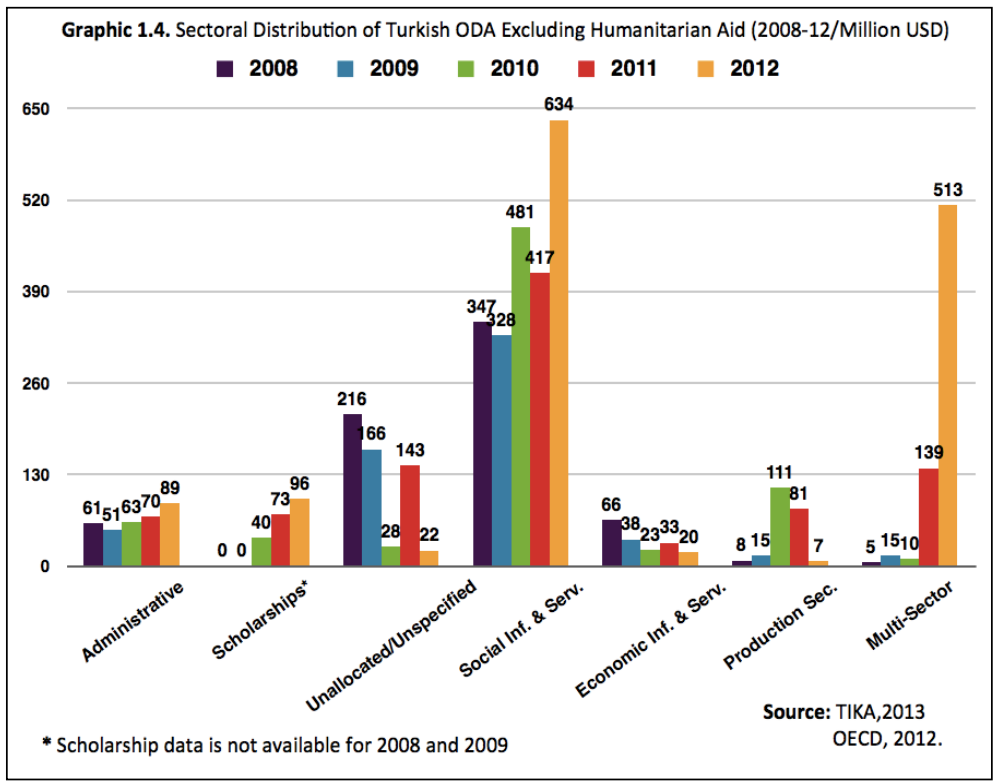

Turkey's development assistance has hinged upon various strengths some of which are caused by Turkey's own merits while others are the result of the international conjuncture. In the last decade, Turkey's economic progress and political stability in the last decade has triggered demands from all around the world to learn from the Turkish experience on several policy fields ranging from macro economy to social safety. Most of these demands have been from the 
countries periodically exposed to protracted conflicts, crises and violence. Geographical proximity to these countries has also been another factor since that many fragile states are clustered in Turkey's neighboring regions.

Reinforced by ethnic, cultural and historical factors along with its non-colonialist past, Turkey's relatively untainted reputation paves the way for a more sincere and open relationship not only with recipients but also other emerging development partners. This advantage is further bolstered by government's current political will to enhance and deepen Turkey's development assistance endeavors as well as its approach to ODA concept as an integral part of Turkish foreign policy ${ }^{25}$.

The progress made by Turkey on some of the most significant development challenges, with which fragile states still struggle, is another asset. Since the initiation of Turkey's European Union (EU) membership negotiations in 2005, country's public institutional capacity have been substantially improved in myriad of sectors from justice to environment. During this period, Turkey has also developed its own development practices on several fields and thus emerged as an important player, which has synthesized oriental values with western pragmatism to certain extent. This particular characteristic enables Turkey to address recipient country's needs in an unparalleled manner. More to the point, despite its authenticity, Turkey's development assistance schemes are open and flexible for triangular cooperation with both traditional and emerging donors.

As an ODA recipient for the last 50 years, Turkish government agencies today are eager to engage in development assistance and share what they have learnt so far during the last two decades. Among 21 ministries, 15 of them actively involved in development assistance, often including others, which do not directly carry out development assistance efforts ${ }^{26}$. Furthermore, these agencies have considerable experience on bilateral engagement with other countries as well as international organizations over economic and political issues, which in turn lead to quick operationalization of ideas. For instance, Turkey's efficient disaster response initiatives (i.e. Philippines), public awareness campaigns (i.e. Somalia and Myanmar) and swift deployment capacity (i.e. Libya) in the face of humanitarian crises are well recognized by the international development community ${ }^{27}$.

Some of the characteristics of Turkish ODA originate from Turkey's unique position between the "North" and "South". As a candidate country for EU accession, Turkey has deeprooted relations with the developed world, which, throughout years, has led to the emergence of institutions, policies and legislations of western origins. In contrast, country's socio-political identity arising from its Ottoman heritage enforces Turkey to maintain oriental values along with cultural, political and economic ties with the countries, which were once under the Ottoman rule. In this respect, Turkish decision makers are in a suitable position to synthesize various development assistance approaches of different actors. Such a synthesis poises Turkey between traditional and emerging donors, thus ensuring originality for the foundations of Turkish development assistance.

The last three years have witnessed a steady increase in Turkish ODA particularly in terms of aid delivered to fragile states. Even though, Turkey's development assistance efforts in some fragile states can be criticized as being volatile, stability on the volume of aid has been realized to a certain extent for the last three years (Graphic 1.1). Besides, there is a significant aid concentration on several fragile states, which has a substantial influence not only on stability but also strengthening Turkey's credibility in these countries. More to the point, majority of Turkish ODA operations in fragile states are unconditional and demand-driven which are initiated upon requests from political leaders or even sometimes common citizens. ${ }^{28}$ Such an approach ensures recipient country ownership and hence further facilitates the smooth implementation of aid schemes.

Turkey's above-mentioned strengths in development assistance, however, are undermined by challenging aid effectiveness issues, which occur in various forms. The first one is about reforming Turkey's own legal and institutional structure. According to Radelet, Clemens and 


\section{Deniz Göle}

Bhavnani, "donors that have large bureaucracies, do not coordinate or harmonize with other donors, or have ineffective monitoring and evaluation systems undermine the effectiveness of their own programs" ${ }^{29}$. Similarly, Turkey's judicial background for modern development assistance practices is not adequate in terms of managing a project portfolio worth of billions of dollars. Current legal capacity and instruments lack sophistication and practicality.

96 Secondly, there is no national strategy or plan, hence overarching policy, to guide, coordinate and harmonize institutions' development assistance efforts as well as to prevent disputes among government agencies with respect to authority. Similar disputes often occur over national budget since that several agencies do not simply have appropriations specifically allocated for development assistance.

Efficiency issues do not only originate from insufficient legal background, budget arrangements or the lack of a grand national plan. There is also the problem of modality. Since the beginning of its assistance efforts, Turkey has been unable to carry out its endeavors in an integrated manner, which could accurately match demands with responses as a whole. In other words, as a development partner, Turkey has, so far, primarily addressed to urgent needs of recipient countries via sporadic actions and pet projects instead of complementary programs aiming at building systems for the long run. This has profoundly hindered the aid effectiveness and usually caused critical waste of country's resources.

Institutional capacity is another concern. As of 2013, TIKA has 35 Program Coordination Offices located in 30 countries, which are the main responsible bodies for Turkish ODA abroad. Nonetheless, both number and capacity of these offices are not adequate to coordinate and manage Turkey's development assistance operations altogether. In addition, Turkey's current aid instruments need modification. For instance, Turkey still does not have a center to train recipient country officials particularly in the field of governance in spite of an extensive demand especially from Least Developed Countries (LDCs). As for institutional capacity, it clearly needs substantial improvements to deal with unique conditions in the fragile states since failure to do that sometimes leads to even loss of human lives. ${ }^{30}$

Questions as how to assist fragile states and where to begin have been on the agenda of international development community since 2001. Today, the community generally recognizes that assistance has to start with introducing peace and building state mechanisms. However, Turkey's assistance to fragile states has not been linked with clear peace and state building strategies. What is worse, Turkey continues to disregard the profound relationship between security and development, which is essential to provide aid effectiveness for countries in crises. This issue, to a large extent, stems from insufficient analysis of situation and recipient priorities in the pre-deployment phase.

Lack of efficient situation and priority analysis leads to volatility of Turkish ODA. As it is illustrated in the previous section, the amount of ODA has dramatically changed on a year and country basis. These alterations often lead to further instability for regions in crises by enhancing fragility and causing imbalances among recipients. Moreover, lack of comprehensive programming has so far led to insufficient and volatile aid on the sectors matter most. Low level of assistance in economic sectors and dramatic fluctuations on production sectors are the symptom of spontaneousness, which, dangerously, ignores specific challenges in fragile states. Regardless, tangible effects of Turkish ODA, whether volatile or not, cannot be measured since that Turkey do not have effective monitoring and evaluation mechanisms. Although reporting on a country level is performed to certain extent, dynamic monitoring and long-term impact analysis are still not available.

In 2011, Turkey's ODA has reached a record high with 1.2 billion USD before a new record was broken in 2012 with the amount of 2.5 billion USD. However, Turkey's donor image is hampered by the fact that it still is a net ODA recipient. As of 2012, Turkey received 3 billion USD mostly delivered by the EU with respect to the structural adjustment programs in the framework of membership negotiations. Due to these close political and financial relations with EU along with other traditional donors, Turkey falls short of creating an entirely unique niche for 
its development assistance, which, in turn, broadly prevents the country from seizing crucial opportunities provided by its substantial strengths.

Figure 3.1 Turkey's New Praxis Framework for Official Development Assistance to Fragile States PARADIGM SHIFT: FROM SPORADIC ACTIONS TO SYSTEM-BUILDING PRACTICES

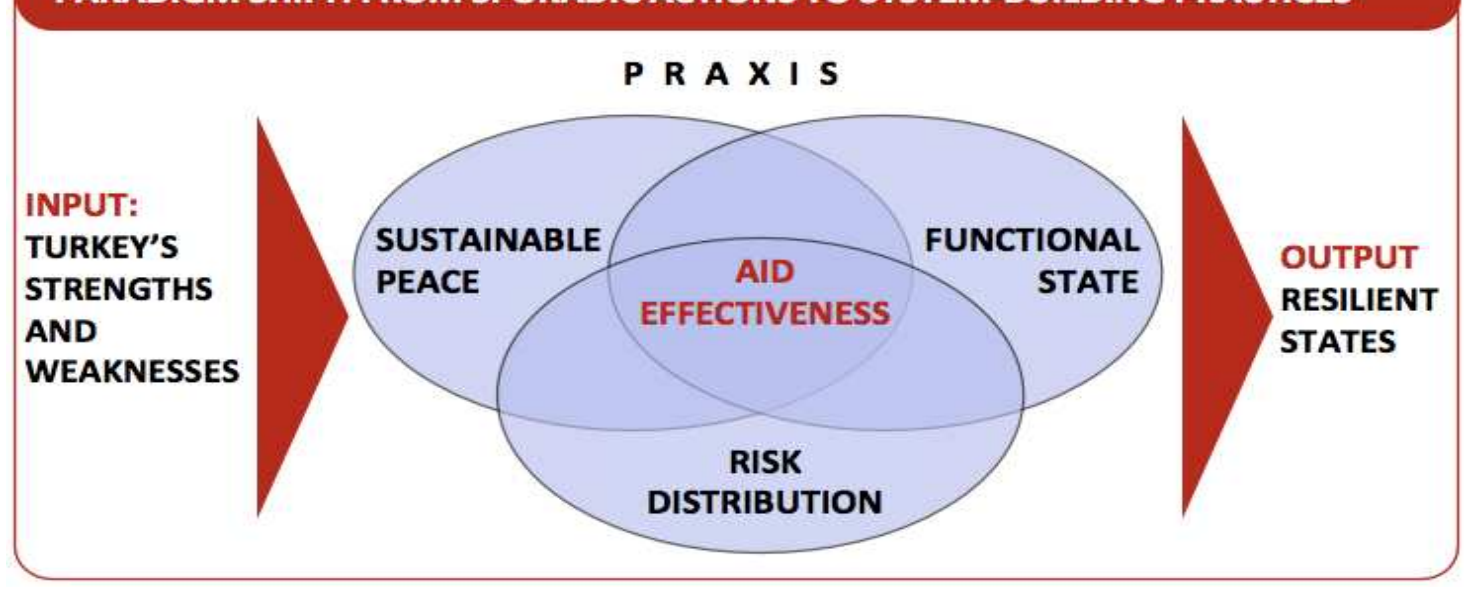

Shifting the Paradigm

In 2009, thanks to its economic and political stability, Turkey has started to pursue a more assertive foreign policy especially with respect to Middle East and North Africa. Starting with neighboring countries in the form of "High Level Strategic Cooperation Councils", the new foreign policy approach has engaged, in due time, with several countries in the region. Based on the "strategic depth" concept developed by Foreign Minister Davutoğlu, the new foreign policy was built upon "Turkey's strengths" arising from its historical and cultural ties as well as the common values shared with the countries in the neighboring region ${ }^{31}$. This new approach envisages using and benefiting from respective factors in policymaking and implementation. The result has been an ambitious Turkish foreign policy with a specific attention to regional politics and conflicts.

Turkey's new foreign policy has intensified country's relations with fragile states since the majority of regional problems and conflicts are related to them. Consequently, the country has undertaken several roles with respect to myriad of policy issues ranging from settling disputes to responding emergencies in countries in crises. Turkey's stance on the IsraeliPalestine conflict, mediation efforts between Afghanistan and Pakistan and humanitarian assistance to Somalia and Myanmar can be considered as sample cases for that matter ${ }^{32}$. This has led to a remarkable increase in the amount of ODA and revealed the need to overhaul Turkish development assistance policy along with its institutional and legal mechanisms.

The first step shall be shifting the current paradigm not only in terms of institutional capacity but also modalities of aid delivery. Turkey is currently deprived of the "operational depth" which would underpin and realize the assertive vision of its foreign policy ${ }^{33}$. As it is explained previously, existing aid efforts have been carried out sporadically instead of integrated actions, which should be designed and implemented by taking into consideration the complexity of needs and conditions in fragile states. While the current modality did not cause significant problems in the past due to Turkey's modest amount of aid, it is not feasible to sustain the business as usual with today's realities.

In this regard, a new praxis to consolidate Turkey's development assistance to fragile states is needed (Figure 3.134). Prioritizing human development, the new praxis has to aim at (i) rehabilitating the problematic relationship between governments and societies in fragile 


\section{Deniz Göle}

states and concurrently (ii) introducing state resilience, which primarily stems from respect to human security ${ }^{35}$, rule of law and civil liberties. To that end, Turkey's aid paradigm must be shifted from sporadic actions to system-building practices. In order to further ensure aid effectiveness and bolster the new paradigm, the praxis shall be constituted upon three pillars; institutionalizing sustainable peace, building functional state, and distributing risks through triangular cooperation.

\section{Institutionalizing Peace}

Peace and stability are the main preconditions for development. Without them, it would be impossible to introduce economic growth, which would be the first step towards ensuring overall development in a country. This is also the case for development assistance. Collier and Hoeffler found that aid in violent situations has no effect on growth whereas in post-war environments, it has a moderate but positive effect on economic growth ${ }^{3637}$. This simply implies that donors must, first and foremost, strive to end the conflict and ensure stability in order to deliver effective aid to the field. More interestingly, aid's impact on growth will increase if the country starts to recover from conflict. Hoeffler et al., suggest that "[...] although total aid does not have a significant impact on growth, it does have a positive, significant impact of about 0.1 percent additional growth if the country is recovering from civil war" ${ }^{38}$.

It is clear from the evidence that Turkey's aid to fragile states should, at the outset, focus on building peace in these conflict affected environments. Nonetheless, peace building needs institutions and with a view to institutionalize peace, three factors are of particular importance; inclusiveness, impartiality, endogeneity.

A durable peace, first and foremost, necessitates different fragments of society to reach the least common denominator. Exclusion of even the most "non-significant" actor might cause instability and restore fragility in the medium or long term. In their influential study, Isham, Kaufmann and Pritchett found that World Bank projects had higher rates of returns in countries with strong civil liberties ${ }^{39}$. Hence, it is critical to include all relevant actors in the process as well as creating a liberal environment where everyone can come into the open, express his/her opinion and contribute to peace.

Another significant factor, however, is to pay due regard to the balance between security and human rights. Although maintaining security is usually the first step towards stability, this cannot be realized by compromising basic rights and freedoms.

Peace building sometimes paves the way for taking sides whether intentional or not. Since introduction of peace requires challenging political decisions, which are usually in favor of one side or the other, it is difficult for donors to remain impartial during the process. Yet impartiality is the key for a successful and effective assistance in fragile states. Legitimacy of a political authority, which is likely a prime partner during development assistance, might turn out to be non-existent in time. This might also be the case for civil society or other nonpolitical actors. What is worse, conflict and instability could overshadow public opinion by putting pressure on society, making it difficult for donors to determine the legitimacy of political actors. To avoid these risks, therefore, Turkey shall treat all parties equally and objectively while trying to enable peace during its endeavors.

Last but not least, Turkey should take into consideration the internal dynamics and priorities of the recipient fragile state. Radelet, Clemens and Bhavnani argue that "aid would be more effective if there were greater 'country ownership' or broader 'participation' among government and community groups in recipient countries [...] ",40.

Nonetheless, ensuring recipient's ownership, and thus effectiveness, is possible merely with addressing the needs and demands when and if they are properly determined by political 
and/or civil actors in the field. Most effective tools to realize endogeneity, in this respect, are peace agreements. Such agreements can only last if they are based on the feedback of all parties as well as proper enforcement mechanisms, otherwise it is improbable to break the cycle of violence and reduce fragility. On the other hand, endogeneity certainly, does not refer to a utopia where everyone is fully satisfied with settlements, but it rather aims at prioritization of demands and enabling an environment for quid pro quo, which could, ultimately, lead to institutionalization of peace.

Introducing sustainable peace is an endeavor that goes beyond simply maintaining security and building law enforcement capacity. Instead, it requires settling disputes between governments and restless societies. Possessing an untainted image in the eyes of many communities, Turkey has a significant opportunity and experience in mediating between conflicting parties, maintaining co-existence and ensuring social cohesion. It is evident that some of the conflicts cannot be settled by Turkey alone due to a number of factors such as insufficient capacity or simply security. In these cases, Turkey can choose either to cooperate with other donors experienced in the field or be involved in joint efforts orchestrated by credible multilateral organizations like United Nations or European Union. In this respect, it is crucial to perform political and technical analyses to evaluate whether an aid scheme needs other actors' involvement or not.

Interaction is also possible between different development objectives. For instance, peace and state building efforts can and should be carried out simultaneously to provide effective solutions to deep-rooted problems. Thus, intertwined peace and state building efforts cannot be deemed as problematic as long as both of them aim at realizing the same basic objectives mentioned above (mediation, co-existence and social cohesion). Still it is essential to make case-by-case evaluation for Turkey in terms of analyzing whether its implementation capacity for synchronized activities is adequate or not.

\section{Building Functional State}

Social and economic development can only be introduced by sound and "inclusive" institutions. According to this argument championed by Acemoğlu and Robinson, the structure and inclusiveness of public institutions play a key role for socio-economic progress and hence alleviating poverty. Only they can promote innovation and restrain cronyism and thereby provide equal opportunities and incentives for investors, which, as a result, paves the way for development. On the other hand, countries having "extractive" institutions, which substantially disrupt free market economy in favor of elites, are not able to advance, consequently become poor and fragile for decades ${ }^{41}$.

Furthermore, there is a strong positive correlation between aid and economic growth only if the recipient country has a "good policy environment". Burnside and Dollar proved that aid has a positive impact on growth only in developing countries with good fiscal, monetary and trade policies whereas in the presence of poor policies, aid has no effect on growth at all ${ }^{42}$. Same authors (along with Collier) later found out that policy and institutional quality are also significant factors that profoundly affect aid-growth relationship ${ }^{4344}$.

In this view, concentrating on building inclusive and resilient government agencies as well as introducing robust economic policies in fragile states is critical, since that assistance disregarding such factors will certainly fail to make real contributions to the development path of countries in crises. In this vein, Turkish ODA shall, at the outset, deal with state's three core functions which are ensuring citizen security and private ownership; protecting individual rights and freedoms via the rule of law; and preserving human dignity through effective social safety nets and sound public finance systems. In fact, fragility usually originates from deficiencies in at least one of these functions, which bring state's authority into a halt. Such 


\section{Deniz Göle}

deficiencies, if not addressed in time, can cause social unrest, collapse of governments or even regimes.

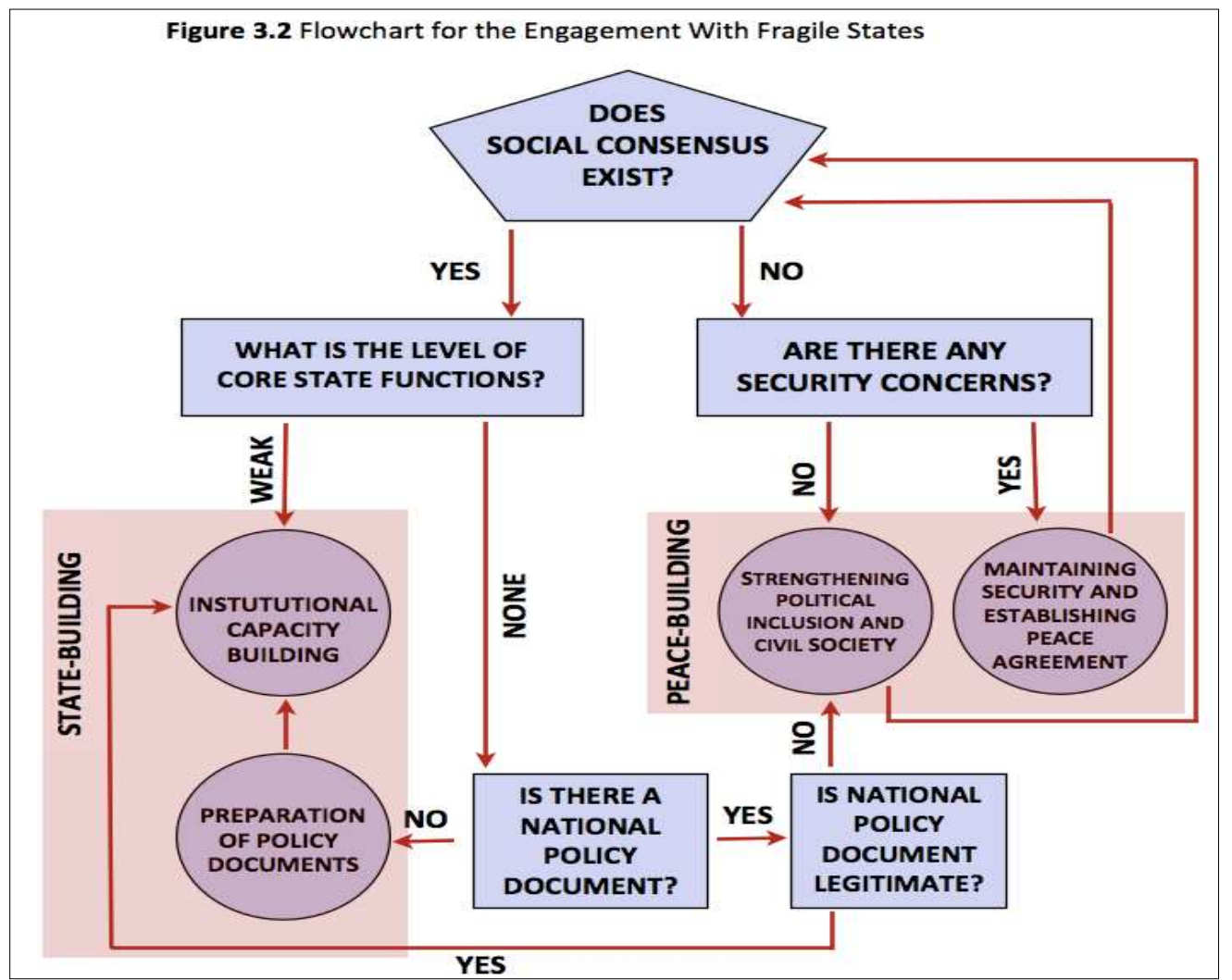

In this sense, assistance should start with the rehabilitation or constitution of public finance systems which are crucial for states to provide basic services for its people. By providing relevant know-how, state mechanisms must be re-oriented to build sufficient capacity in collecting revenues particularly with regard to the fields/sectors generating significant income. Focusing on other sectors such as health, education etc. before public finance is unfeasible since states without financial means are not able to sustain the initiatives started by donors. They probably cannot even cover recurring expenditures even in the short run. Therefore, it is of the utmost importance to concentrate on public finance system before all else.

Building core state functions is a great challenge and requires certain tasks to be performed one step at a time (Figure $3.2^{45}$ ). At the outset, Turkish officials shall familiarize themselves with national policy documents such as development plans or poverty reduction strategies of recipient countries. If there are none, the objective ought to be the preparation of policy documents defining national priorities and targets, which have to be simple and realistic with a view to ensure feasibility and transparency. Upon the finalization of policy documents and harmonization of priorities (between Turkey and recipient country), capacity building for core state functions can be initiated.

At all levels of capacity building, social inclusion and good governance must be pursued. This is especially vital for normalization of state-society relations, taking into account the importance of dialogue mechanisms in the period of premature peace. There is no doubt that antagonist policies and exclusionist practices lead to instability and even pose threat to already vulnerable peace. To avert that, Turkey should try to constitute sustainable 
mechanisms for inclusion, transparency and accountability not only during development assistance but beyond.

\section{Risk Distribution}

Dealing with fragile states' demands under challenging circumstances might exceed one donor's capacity. Keeping peace often necessitates a multilateral intervention or creating a public financial system might require technical know-how of specialized institutions (i.e. World Bank). In such cases, Turkey could be involved in triangular cooperation mechanisms.

Multilateral cooperation mechanisms are particularly important for development assistance to fragile states. In these formidable environments, aid effectiveness can only be possible with risk distribution, division of labor and hence specialization. Indeed, there is a direct correlation between aid effectiveness and risk undertaking. On the one hand, donors are under a remarkable risk pressure stemming, inter alia, from political instability, corruption and lack of institutional capacity, on the other they have to deliver efficient aid outputs. What is worse, measures taken (i.e. bypassing country systems ${ }^{46}$ ) to minimize risks, unfortunately, undermines the effectiveness of aid.

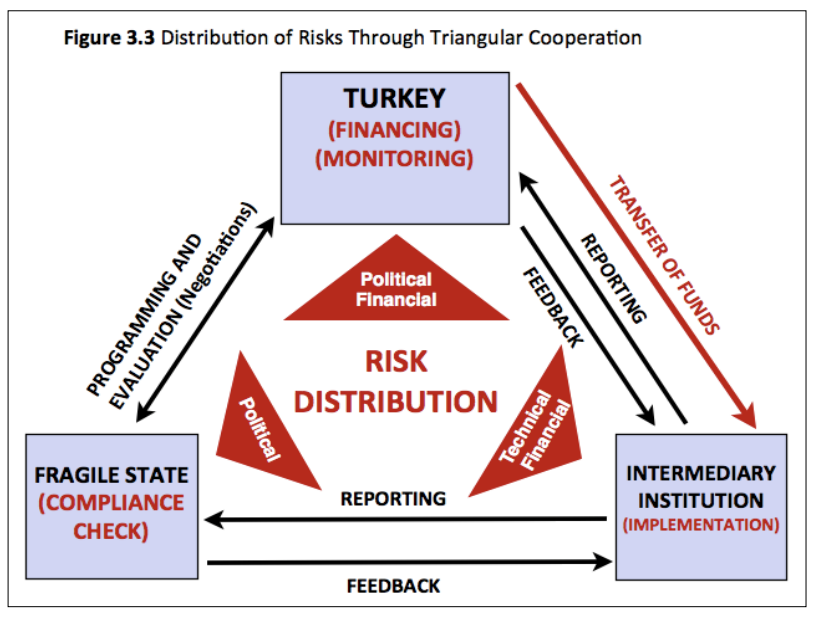

Turkey, in this regard, should distribute risks in cooperation with other actors. With a view to operationalize risk distribution, it is critical to engage in triangular cooperation, which basically includes Turkish public institutions along with the ones in fragile states and national or multilateral donor agencies (Figure $3.3^{47}$ ). These agencies, above all, have to be experienced in project-related operations, hire residential staff and thus, have strong field presence in the respective country. They can either be international (i.e. UNDP, World Bank), national (i.e. DFID, JICA, SIDA) or non-governmental organizations (i.e. Doctors Without Borders). However, Turkey should show due diligence when choosing a third party for its development assistance projects, since that some donors (whether national or international) might have a bad reputation in target countries.

The rationale behind triangular cooperation is to transfer technical and financial risks to partners (intermediary agency) while undertaking political ones. In this framework, Turkey shall consider commissioning, to certain extent, the implementation of ODA activities particularly in countries on which Turkey has limited or no experience and presence at all. The modalities and terms of this commission, naturally, have to be determined by Turkish institutions in consultation with relevant recipient parties. While priorities, field of application and methodology of development assistance are specified with beneficiary institutions in the recipient country, implementation modalities should be designed with intermediary agencies (distribution of technical risk). After the finalization of these procedures, Turkey could transfer relevant funds to intermediary agency (distribution of financial risk) and agency becomes accountable to both Turkey and recipient country for the implementation of activities in line with the agreed modalities and terms. The overall progress can be monitored by all parties through regular reporting activities and course-correcting feedback.

\section{Policy Implications and Conclusions}




\section{Deniz Göle}

In 2005, international community has set various indicators to measure aid effectiveness together with ambitious targets in a high level global forum held in Paris. However, an evaluation report published 7 years later has revealed that donors have significantly fallen behind their aid effectiveness targets ${ }^{48}$. The disappointment followed by this failure has paved the way for seeking new aid modalities and cooperation opportunities particularly with emerging donors.

Turkey has been, for some time, the object of traditional donors' interests not only due to their awareness of cooperation but also the considerable increase in the amount of Turkish ODA. Nonetheless, while trying to introduce "strategic depth" to its foreign policy, Turkey continues to implement archaic methods instead of reforming ODA policies and practices to adapt to today's aid architecture. This challenge poses a significant threat to Turkish development assistance, since that failing to ensure aid effectiveness via innovative tools and practices would probably undermine Turkey's remarkable advantages in the field. More importantly, bearing its strengths and weaknesses in mind, Turkey's current aid paradigm is inadequate to address fragile states' development issues and thus needs to be altered in three steps.

First, Turkey should embrace a new understanding (i) designed within the framework of tailor-made 'rules of engagement' with recipient countries (differential diagnosis), (ii) enabling multi-sectoral activities with a specific attention to "Whole-of-Government" approach, and (iii) focusing not only on urgent needs but also long-term development challenges of fragile states.

Secondly, Turkey has to focus on building and institutionalizing sustainable peace with respect to its aid programs in war-torn countries. To do that, it should first deal with problematic relations between state and society by reaching beyond simple capacity building and technical cooperation activities. Thanks to its current credibility, Turkey is in a suitable position to perform relevant tasks such as conciliating conflicting parties, facilitating coexistence and ensuring social cohesion. Moreover, core state functions shall be strengthened simultaneously, for development assistance neglecting state building cannot provide substantial contributions to long-term development endeavors of fragile states.

Lastly, operational and financial risks must be addressed in cooperation with third parties. Triangular cooperation is an effective tool to that end by distributing risks and realizing effective aid schemes. More to the point, it is critical for Turkey to take into consideration three factors namely strategic engagement, flexibility and policy coherence with a view to combine the three pillars of its new ODA praxis. Only then, will Turkey be able to synthesize the practical approach of traditional donors with the idealism of emerging ones and consequently provide distinguished solutions to protracted development issues of fragile states.

\section{Notes}

\footnotetext{
${ }^{1}$ Fernanda Faria and Patricia M. Ferreira, "An Adequate EU Response Strategy to Address Situations of Fragility and Difficult Environments.” European Centre for Development Policy Management (2007), 5.

2 OECD, 2012. This significant concentration arises from the fact that majority of countries, with which Turkey has cultural, historical or ethnic ties, is classified as fragile today.

3 Deniz Göle. Kırılgan Devletlerde Uygulanan Kalkınma Yardımı Programları ve Türkiye İçin Etkin Yardım Modalitesi Önerisi, (Ankara: Kalkınma Bakanlığı, 2013), 12.

${ }^{4}$ OECD. "The Paris Declaration on Aid Effectiveness and Accra Agenda for Action". (Paris: OECD, 2011).

${ }^{5}$ William Easterly. The White Man's Burden: Why the West Efforts to Aid the Rest Have Done So Much Ill and So Little Good. (New York: Penguin, 2006), 50.
} 
${ }^{6}$ Steven Radelet, Michael Clemens, and Rikhil Bhavnani. "Aid and Growth: The Current Debate and Some New Evidence." The Macroeconomic Management of Foreign Aid: Opportunities and Pitfalls (2006), 14.

7 Stephen Knack. "Aid Dependence and the Quality of Governance: Cross Country Empirical Tests." Southern Economic Journal 68 (2004), 310-29.

${ }^{8}$ Radelet, Clemens and Bhavnani, op cit., 9.

${ }^{9}$ Asli D. Kunt, Thorsten Beck and Ross Levine. "Small and Medium Enterprises, Growth and Poverty: Cross-Country Evidence." World Bank Policy Research Working Paper No. 3178 (2003).

${ }^{10}$ Marcel Fafchamps, and Bart Minten. "Property Rights in a Flea Market Economy." Centre for the Study of African Economies (1999).

${ }^{11}$ Jeffrey Sachs. The End of Poverty: Economic Possibilities of Our Time. (New York: Penguin, 2005), 80-89.

12 Easterly, op cit., 37-59.

${ }^{13}$ OECD. "OECD Stat Extracts.” Accessed June 12, 2014, (http://stats.oecd.org/) and TIKA. "Çevrimiçi Veri Tabanı". Accessed June 12, 2014, (Restricted Access)

${ }^{14}$ Idem.

15 The fragile list classification used in this article is based upon OECD's classification consisting of 47 countries. See OECD, 2011b.

${ }^{16}$ OECD. "2011 OECD Report on Division of Labour: Addressing Cross-Country Fragmentation of Aid", (2011), 5-6.

17 OECD. "OECD Stat Extracts.” Accessed June 12, 2014, (http://stats.oecd.org/) and TIKA. "Çevrimiçi Veri Tabanı". Accessed June 12, 2014, (Restricted Access)

182012 statistics by type of aid is not available as of December 2013.

${ }^{19} 2012$ statistics by sectoral distribution is not available as of December 2013.

${ }^{20}$ OECD. “OECD Stat Extracts.” Accessed June 12, 2014

http://stats.oecd.org/

${ }^{21}$ TIKA. Türkiye Kalkınma Yardımları Raporu 2011. (Ankara: TİKA, 2012), 96.

22 TIKA, 2012: 52-56.

${ }^{23}$ TIKA. Türkiye Kalkınma Yardımları Raporu 2012. (Ankara: TİKA, 2013),14-92, TIKA. "Çevrimiçi Veri Tabanı". Accessed June 12, 2014, (Restricted Access) and OECD. "OECD Stat Extracts." Accessed June 12, 2014, (http://stats.oecd.org/).

${ }^{24}$ OECD. "OECD Stat Extracts.” Accessed June 12, 2014, (http://stats.oecd.org/).

25 Ibid., 4-5.

26 TİKA, 2013: 102-120.

${ }^{27}$ OXFAM Blog. “A Muslim Tiger? Turkey’s rising power and influence.” Accessed August 4, 2014 http://www.oxfamblogs.org/fp2p/?p=12591

${ }^{28}$ In 2011, the President of Turkey Abdullah Gül gave his word to provide relevant equipment for a Gabonese fisherman upon his direct request. http://www.hurriyet.com.tr/gundem/20969039.asp

${ }^{29}$ Radelet, Clemens and Bhavnani, op cit., 6.

${ }^{30} \mathrm{http}: / /$ www.ifrcmedia.org/blog/turkish-red-crescent-convoy-attacked-in-somalia/

${ }^{31}$ Ahmet Davutoğlu. Stratejik Derinlik. (İstanbul: Küre, 2009).

${ }^{32}$ Karen Kaya. "Turkey's Role in Afghanistan and Afghan Stabilization." Military Review XCIII- No.4 (2013), 23-30.

${ }^{33}$ Çă̆atay Telli. "Dış Politikaya Operasyonel Derinlik Kazandırmak: Kalkınma İşbirliği Programları."

(T.C. Kalkınma Bakanlığı, 2011).

${ }^{34}$ Designed by the author.

${ }^{35}$ UN Commission on Human Security. "Human Security Now." (New York: UN, 2003), 5.

${ }^{36}$ Paul Collier and Anke Hoeffler. "Greed and Grievance in Civil Wars." Oxford Economic Papers 56 (2004), 563-595

37 Anke Hoeffler, Syeda S. Ijaz, Sarah Von Billerbeck. "Post-conflict Recovery and Peace Building." Background Paper for the Word Development Report, World Bank, 2011.

${ }^{38}$ Hoeffler et. al.,op cit., 21.

${ }^{39}$ Jonathan Isham, Daniel Kaufmann, and Lant Pritchett. "Governance and Returns on Investment: An Empirical Investigation.” World Bank Policy Research Working Paper No. 1550 (1995).

${ }^{40}$ Radelet, Clemens and Bhavnani, op cit., 6. 


\section{Deniz Göle}

${ }^{41}$ Daron Acemoglu, and James Robinson. Why Nations Fail: The Origins of Power, Prosperity and Poverty. (New York: Crown, 2012), 70-124.

${ }^{42}$ Craig Burnside and David Dollar. “Aid, Policies and Growth.” World Bank Policy Research Working Paper No. 569252 (1997).

${ }^{43}$ Paul Collier, and David Dollar. "Aid Allocation and Poverty Reduction." European Economic Review | 104 46 (2002): 1475-1500.

${ }^{44}$ Craig Burnside and David Dollar. "Aid, Policies and Growth: Revisiting the Evidence." World Bank Policy Research Working Paper No. 3251 (2004).

${ }^{45}$ Designed by the author.

${ }^{46}$ Country systems refer to all legal and institutional arrangements in a country in a given time.

${ }^{47}$ Designed by the author.

${ }^{48}$ Göle, op cit., 76.

\section{List of Graphics Boxes and Figures}

Graphic 1.1 Turkish Official Development Assistance

Graphic 1.2 Distribution of Turkish ODA

Graphic 1.3 Turkish ODA to Iraq, Pakistan and Kyrgyzstan

Graphic 1.4 Sectoral Distribution of Turkish ODA Excluding Humanitarian Assistance

Graphic 1.5 Turkey's ODA Distribution of Social Infrastructure and Services

Box 1.1 "Peace Building" Efforts Under Turkish ODA

Figure 3.1 Turkey's New Praxis Framework for Official Development Assistance to Fragile States

Figure 3.2 Flowchart for the Engagement with Fragile States

Figure 3.3 Distribution of Risks Through Triangular Cooperation 